Baitenova N. Zh., Demeuova A.A.

C.G. Jung and E. Fromm psychoanalytic paradigm of the phenomenon of religion

Байтенова Н.Ж., Аемеуова А.А.

К.Г. Юнг и Э. Фромм дін феноменінің психоаналитикалық парадигмасы туралы

Байтенова Н.Ж., Аемеуова А.А.

К.Г. Юнг и Э. Фромм о психоаналитической парадигме феномена религии
The article is devoted to one of the brightest representatives of the psychoanalytic concept of religion C.G. Jung and E. Fromm. C.G. Jung paid great attention to the archetypes, in his opinion, it is an archetypal content of the psyche is the basis of religion. Archetypes express deeper and more intimate side of the human soul and are a kind of determiner man's inner life. According to C.G.

Jung loss of religiosity actually mean the loss of the man himself. C.G. Jung considers religion as an important condition for the mental health of the person, in connection with which connects the growth of mental illness with the decline of religious faith. E. Fromm critical of the idealistic constructions Jung and generally adhered to Freud's ideas about the structure and dynamics of mental processes, but at the same time and made some adjustments and their additions to the question about the impact of social conditions on the nature of the human psyche.

Key words: C.G. Jung, E. Fromm, the psychoanalytic concept of religion, archetype, religion, religious, authoritarian and humanistic religion.

Мақала діннің психоаналитикалық концепциясының көрнекті өкілдерінің бірі К.Г. Юнг и Э. Фром арналған. К.Г. Юнг архетип мәселесіне көбірек көңіл бөледі, оның пікірі бойынша, психиканың архетиптік мазмұны діннің негізін құрайды. Архетиптер аАам жанының неғұрлым терең және жасырын жақтарын құрайды және де адамның ішкі дүниесінің өзіндік бір детерминаторы болып табылады. К.Г. Юнг пікірі бойынша, аАам бойындағы діндарлықты жоғалту адамның өзін жоғалтумен тең деп қарастырды. Юнг дінді адам психикалық, денсаулығының маңызды шарты деп қарастырады, осыған байланысты, психикалық аурулардың көбеюін діни сенімнің төмендеуімен байланыстырады. Э. Фромм Юнгтың идеалистік ұстанымдарына сыни көзбен қарап негізінен психикалық процестердің құрылымы мен динамикасы мәселесі бойынша фрейдтік көзқараста болды, бірақ, сонымен қатар, адам психикасының табиғатына әлеуметтік жағАайлардың әсері туралы толықтырулар мен түзетулер енгізді.

Түйін сөздер: К.Г. Юнг, Э. Фромм, Аін тура^ы психоаналитикамық концепция, архетип, Аін, Аіндарлық, авторитарлы және гуманистік Аіндер.

Статья посвящена одним из ярких представителей психоаналитической концепции религии К.Г. Юнгу и Э. Фромму. К.Г. Юнг уАеля^ большое внимание архетипам, по его мнению, именно архетипическое содержание психики составляет основу религии. Архетипы выражают более глубокие и сокровенные стороны человеческой души и яв^яются своеобразным детерминатором внутренней жизни человека. Согласно К.Г. Юнгу, утрата религиозности на самом деле означает утрату человеком самого себя. К.Г. Юнг рассматривает религию в качестве важного условия психического зАоровья человека, в связи с чем связывает рост психических заболеваний с упадком религиозной веры. Э. Фромм критически относияся к идеалистическим построениям Юнга и в целом придерживался фрейдовских представлений о структуре и динамике психических процессов, но вместе с тем внес и свои определенные коррективы и дополнения в вопросе о влиянии социальных условий на природу человеческой психики.

Ключевые слова: К.Г. Юнг, Э. Фромм, психоаналитическая концепция религии, архетип, религия, религиозность, авторитарные и гуманистические религии. 


\section{C.G. JUNG \\ AND E. FROMM PSYCHOANALYTIC PARADIGM OF THE PHENOMENON OF RELIGION}

\section{Introduction}

The Ideas of psychoanalytic concept of religion were developed by C.G. Jung and E. Fromm, whose views were different from those of Freud.

C.G. Jung was one of the founders of the psychology of religion and analytical psychology, representative of nondenominational wing of modern religious modernism. To show the fundamental difference, and not agree with the psychoanalysis of Freud, he called his psychology analytical psychology.

The original and significant contribution to the development of the psychoanalytic concept of religion has been introduced by world-renowned psychoanalyst and philosopher Erich Fromm. After World War II Erich Fromm had a significant impact on the development of the psychology of religion, whose name is linked to a new stage in the further development of the psychoanalytic concept of religion. A committed follower of Freud, he was critical of the idealistic constructions Jung and generally adhered to Freud's ideas about the structure and dynamics of mental processes, but at the same time, and made some adjustments and their additions to the question about the impact of social conditions on the nature of the human psyche.

\section{religion \\ C.G. Jung's archetypal content of the psyche as the basis of}

Jung, like Freud, their position is similar, considering the religion, the problem of religion in indissoluble unity with psychology. On this occasion, in his famous paper «Psychology and Religion» C.G. Jung gives the following explanation: «... my task, I believe, would be to show what is common between religion and psychology and what it can tell us about religion. More precisely, not all psychology, but a special branch of medical psychology, which I represent. Because of religion is one of the earliest and most universal activities of the human mind, it is obvious that any kind of psychology, addressed the issue of the psychological structure of the human personality, inevitably faces, at least, to the fact that religion is not only a sociological or historical phenomenon, but it has per- 
sonal significance for a large number of individuals. « Jung believes that «... religion has a very important psychological beginning ...» [1, p. 3].

Jung gives a detailed understanding of religion: «Religion is a special setting of the human mind, which we can determine, in accordance with the original use of the concept of «religio», i.e., careful examination, observation by some dynamic factors, understood as «strength» spirits, demons, gods, laws, ideas and ideals - and all the other names given to a man like factors discovered them in his world as a powerful, dangerous; or able to provide such assistance, that they should be considered; or rather majestic, beautiful, meaningful, to love them and reverently bow before them. In everyday parlance we often say that a man who enthusiastically interested in some subject, «devoted himself to» the case; William James says, for example, that a scientist often has no faith, but «he is devout in spirit.» It is clear that when I am using term «religion» I do not mean faith. It is true, however, that every doctrine is based, on the one hand, the experience of numinous, and on the other - on piotiv, on loyalty, fidelity, and trust in a certain way was influenced numinous and subsequent changes of consciousness. A striking example of this can serve as an appeal of the Apostle Paul. We can say that «religion» is a concept that refers a particular installation of consciousness, altered by experience of numinous» [1, p. 5]. Consequently, Jung considers religion as a unit, the generation of the human mind which formed by influence of experience of numinous.

Scientific interest of Jung differed with depth and innovative approach to religious and psychological issues as he comes from a theological environment and this has left its mark on his outlook and his work. Jung has written more than twenty works devoted to religious issues directly. The most famous of his works are the following: «Psychology and Religion» (1938), «The symbolism of transformation in the Mass» (1942-1945), «The psychological approach to the dogma of the trinity» (1942-1948), «Answer to Job» (1952) and other works.

Jung was a stranger to «scientific materialism» and Freud's atheism. Jung described his position as follows: «I, describing its position on this matter, to give a positive value to all religions», i.e. he positively considers religion [2, p. 137]. Also unlike Freud from Jung's religion is not put in direct dependence on the human neurotic states. His disagreement with Freud, Jung expressed the position in respect of aggressive sexual impulses, to the place which, according to Freud, have come to religious ideas. Jung also disagree with Freud's interpretation of religious symbols such as the images of the god and goddess, who in the interpretation of Freud presented as a projection image of the real parents. But at the same time, Jung expresses strongly disagree with Freud's «Oedipus complex.»

Jung was not limited to study only individual psychological manifestations of religiosity, moreover, unlike Freud, the unconscious as a factor in considering religion is not on a personal level, which includes the forgotten, repressed, unconscious experiences accumulated during the life of the individual as well as the collective unconscious.

Jung, in his work «The affect civilization,» writes: «... the surface layer of the unconscious is a certain degree of personality. However, this layer is based on a different, deeper, leading its origin is not from personal experience. This innate deeper layer is the so-called collective unconscious. ... The collective unconscious is identical in all people, and thus forms a universal thorough identical in all people, and thus forms a universal foundation of every spiritual life, being by nature supra» $[3$, p. 76].

The collective unconscious, according to Jung has layering of family, tribal, national, human experience, as well as the echoes of human prehistory. The collective unconscious is associated with such universal fundamental universal manifestations of human life as birth, love, life, death, and enshrined in the human psyche as congenital.

Collective Unconscious expresses itself in symbolic, figurative form, is common to all mankind, universal. The content side of the collective unconscious are archetypes. In recognition of this concept Jung he borrowed from St. Augustine, also has a certain similarity with the concepts of «the image of God in man» Philo of Alexandria, and the «ideas» of Plato [4, c. 170].

Jung paid great attention to the archetypes, in his opinion; an archetypal content of the psyche is the basis of religion. Archetypes express deeper and more intimate side of the human soul and represent a kind of determiner man's inner life.

Jung defines archetypes as follows in his «Psychology and Religion»: «... a dream made up of highly collective material - just like in the mythology and folklore of various nations, some motifs are repeated in almost identical form. I call these motives «archetypes», by which I mean the forms and images, collective in nature, occurring in almost all the land as an element of myth and are at the same time autochthonous individual products of unconscious origin. Archetypal motives originate from archetypal images in the human mind that are transmitted not only through tradition or migration, 
but also by means of inheritance. This hypothesis is necessary, since even complicated archetypal images can be spontaneously reproduced without any traditions» $[1$, p. 31$]$.

The formation of analytical psychology of Jung was influenced not only Freud but also other scientists, particularly R. Otto with his idea of numinous. Under the influence of R. Otto, Jung considers archetypes like numinous force. Religious i.e. numinous experience Jung regarded as a manifestation of psychic experience, as a manifestation of sensible powerful psychic forces and existential meaning, which are concentrated in the archetypes. Jung writes: «... If we were still living in the medieval world, where there were serious doubts about the latter grounds where the whole history of the world began with the book of Genesis, we could easily brush aside dreams and all the like. Unfortunately, we live in a world where the latest dubious grounds, where you have to take into account the rich background, where people are convinced that if the numinous experience is generally the case, it is the mental experience ...» [1, p. 36-37].

Convinced Jung in religious beliefs embodied not the reality of the external world, but psychic reality. Jung based on the theory of «psychic reality». According to this theory, a person may rely on two types of evidence: physical and mental. The first type of facts is phenomena associated with the external, objective world. To the second type of facts are those phenomena that cannot be neither proved nor explained, nor, moreover, refuted. This category includes the reality of dreams, fantasies, different beliefs, etc., in this case we are talking about the «psychic reality.» This approach allows Jung argued that «God is the obvious mental, not a physical fact, i.e., a fact which can be established only mentally, but not physically» [5, p. 464].

Jung criticizing the traditional Christian understanding of God as transcendent, anthropomorphic creatures, never intended to undermine the foundations of religion. Despite of he was more scientist than a theologian, above all, a representative of analytical psychology, Jung denying God's ontological status, he was trying to protect religion from the most vulnerable places in terms of science.

An attempt to interpret Jung's God as a projection of mental processes has led to the replacement of a transcendent God immanent (i.e. the God within us) that makes God a closer and clearer, and religion becomes an integral feature of human existence.

Jung, unlike Freud, who defined religion as «collective obsessional neurosis», considered a neurosis resulting from loss of religiosity. According to Jung, the position of all members of the psychoanalytic theory are the same, all mental illness is the result of an imbalance between the conscious and the unconscious, when a person ceases to understand its nature, i.e., unconscious. Religion gives to person socially sanctioned forms of actualization of unconscious mental processes through archetypal images.

Originality of Jung's approach is manifested in the fact that he sees in religion a universal and highly effective system of psychotherapy. According to Jung, psychotherapeutic properties of religion is not limited to purely doctoring, but also a number of features peculiar to religion as an essential for life as an individual, and, in general, for the whole society.

Religion performs a compensatory function, reconciling man with a variety of negative manifestations of human existence, serves as an integrating force, ordering the consciousness and behavior, and also performs the function of worldview, giving people faith, hope and love, what most people need. Jung came to the conclusion that the loss of religion actually means the loss of the man himself. Jung considers religion as essential for mental health. In this connection, it connects the growth of mental illness with the decline of religious faith [6].

\section{Erich Fromm about the existential nature of religion}

Erich Fromm's interest in the social aspects of personality was influenced by the philosophy of Ludwig Feuerbach and Karl Marx, as well as tight, although short-term co-operation with representatives of the Frankfurt School of philosophy and sociology of M. Horkheimer, Adorno, H. Mapkuze. Erich Fromm talking about human nature, says that modern man has achieved a lot, it made more perfect their social environment, their environment. In his work «Psychoanalysis and religion», he writes: «Never before has man come so close, as today, to exercise their most cherished hopes. Our scientific discoveries and technological advances approximate time table will be covered for all the hungry, when humanity will overcome disunity and becomes one. It took millennia to reveal the intellectual abilities of man, that he learned the rational organization of society and the concentration of forces. Man has created a new world with its own laws and their own destiny. Looking at his creation, he can say, indeed, that's good».

Indeed, people achieved a great deal in improving your social life, here, I mean, first of all, a Western man. For the main difference between Western and Oriental world it is that Western people are more 
involved in improving the external of the world, and the oriental people more concerned about the state of his inner world, so drew more attention to the internal improvement, to improve their spiritual world.

In connection with the situation at the Erich Fromm raises the question whether the person lives up to its designation as an earthly viceroy of God on earth, as the image and likeness of God: «But what did he say about himself? He approached the implementation of the other dreams of the human race the perfection of man himself? - A man who loves his neighbor, just, truthful and implements what it has the potential, as the image of God? Embarrassing even to ask the question - the answer is too obvious. We have created a wonderful thing, but could not make himself creatures that would be worthy of the enormous effort spent on these things. In our life there is no brotherhood, happiness, satisfaction; it is - a spiritual chaos and jumble close to madness - and not to the medieval hysteria, but rather to schizophrenia - when lost contact with the inner reality and the idea was separated from the passion» [7, p. 150].

Erich Fromm in his famous work «Zen Buddhism and Psychoanalysis» connects the degree of religiosity of a man with his ability to answer the existential questions: "Man is a» religious «if he comes to this fundamental issue is not formally, but seeks to give an answer to it all their lives. Similarly, any system is a «religion» if it tries to give an answer to this question, and urges people to it. ... Every culture and every person who is not looking for an answer to the existential question, not religious in nature - the best example being the man of the XX century».

And this situation is due to the fact, according to Erich Fromm, that one replaces the existential questions of the material issues the plan: «Preoccupied with thoughts of material wealth, prestige, power, career, modern man tries to avoid answering this question, trying to forget about the fact its existence ... without their own answer man is not able to develop in his life and death, resembling one of the millions of things made by him». In this situation, «it does not matter how deep his religious beliefs, how often he thinks about God and attends church. Such man instead of believing in God just thinking about it». [8, p. 217].

Erich Fromm has a number of papers on various issues of the psychology of religion. Among these, the most interesting are such works of Erich Fromm as «Psychoanalysis and Religion», «Zen - Buddhism and Psychoanalysis», "The doctrine of Christ», «Have or to Be», «You shall be as gods. Radical In- terpretation of the Old Testament and its traditions «and other works of religion, psychology and culture. As for the most comprehensive understanding of the psychoanalytic concept of religion in general, Erich Fromm and his views on religion had a great importance in his works as «Escape from Freedom», «Forgotten Language», «The Art of Loving,» «Soul Man», «Anatomy of Human destructiveness». Despite the fact that Erich Fromm compared with other pupils and followers of Freud was more exposed to and adhered to the position of Freud, however, an attempt to reform the E. Fromm psychoanalytic concept of religion based on the ideas of Marxism and existentialism, has led to that he became the founder of a new movement - neo-Freudianism.

The principal difference between psychoanalysis Erich Fromm and Freud was the fact that Erich Fromm decided to come up with methods of psychoanalysis to matters which are essentially within the scope of philosophy and ethics: what is right and wrong, good or evil human nature, which is the true nature of man, and what its perversion of the meaning of human freedom and human love.

Freud worked hard in order to not interfere with the morality medicine, Erich Fromm proved every line that the medicine will not do anything without morality: mental health is inextricably linked to the moral position. In fact, he developed his own ethical doctrine, in which both poles of good and evil figure he proposed the concept of a syndrome of growth and decay syndrome.

In his works, «Psychoanalysis and Religion,» «Dogma of Christ», «The Art of Loving» Erich Fromm tries to discover the nature and essence of religion. In considering this issue Erich Fromm came across a problem that is related to the ambiguity of the concept of religion. In «Psychoanalysis and Religion», telling about the revealing nature of the concept of religion, Erich Fromm writes: «The obstacle to any discussion of religion is terminological ambiguity. Although we know that in addition to the monotheistic there are many other religions, but still associate the religion with the system, placed in the center of God and the supernatural; we tend to take the measure of a monotheistic religion to understand and evaluate all other religions. And then we ask ourselves: Is it possible to religion without God, such as Buddhism, Taoism or Confucianism, generally called religion? Such secular system, as a modern authoritarianism was not called religion, but from a psychological point of view, they are quite deserve».

Erich Fromm gives its understanding and definition of this concept: «We simply do not have words 
for religion - as a universal phenomenon - that would not cause any association with this or that particular type of religion. In the absence of such a word I will use in the future, the term «religion»; but would like to make it clear from the outset that under the religion I mean any group shared system of thought and action that enables the individual to lead a meaningful existence and giving the object for devotion» [7, p. 157].

That is the conclusion Erich Fromm comes on the idea of the universality of the religious needs of man, which is derived from the human condition. In this broad sense, no culture, past or present, but, apparently, the future cannot be regarded as a culture without religion [7, p. 158].

At the same time people can worship animals, trees, people, class, etc. He himself says that the definition of religion does not say anything about its specific content. The question is not whether religion or not, and in fact, what this religion: whether it contributes to the further development of the person, especially the implementation of its inherent human abilities or prevents its development.

Erich Fromm writes on this subject: «There is no man who would not have religious needs - the need for a system of orientation and object to serve; but it tells us nothing about the specific context of its manifestations. A person can worship animals, trees, gold, or stone idols, the invisible God, the holy man or leaders with a devilish guise; he can worship ancestors, nation, class or party, money or success; his religion may contribute to destructive or beginning of love, oppression, or the brotherhood of man; it can contribute to its cause or the reason the mind into a state of paralysis; a person can be considered a system of religion that differs from the system of secular character, but can also think that he has no religion, and interpret their service to certain supposedly secular purposes - such as power, money or success - just as the concern about the practical and useful. The question is not, religion or lack of it, but what kind of religion: a religion or conducive to human development, the disclosure of the actual human forces, or religion, which paralyzes the forces»(emphasis added) [7, p. 160].

First of all, it emphasizes Erich Fromm: «religious need is rooted in the basic conditions of existence of the human species» [9, p. 141]. In the early stages of development, struggling for survival, people suffer from a lack of understanding of how the forces of nature, and by his helplessness in their use. $\mathrm{He}$ created a theory to explain the nature and invent different ways of conquest, and all this has gradually become a part of his religion.
Erich Fromm calls this aspect of religion, science and magic, because he has a common feature with the science knowledge of nature to improve technology needed for its successful use. The development and the existence of religions Erich Fromm puts dependent on scientific and technological progress which make it possible to improve human abilities. «The more scientific and technical progress, the less the need to impose religion on the tasks that are religious only in the historical sense» [7, p. 167, 298].

As noted above, Erich Fromm focuses mainly on the social factors that contribute to the emergence of belief in gods. At the same time, Erich Fromm is not limited to social factors in religion; he also tries to find the origins of religion in the nature of man himself. Erich Fromm points out that»... human existence is characterized by the existence of all other organisms: it is in a constant state of instability and imminent» [10, p. 237].

Man must, according to Erich Fromm, to overcome the internal discord, aggravated thirst «absolute». Erich Fromm in «Psychoanalysis and Religion», considering the religious experience and, above all, as the analyst identifies the following features.

The first feature of the religious experiences he said, is a form of emotional states such person as a surprise, surprise, awareness of life and its own existence, the mysterious problem of its connection with the world. Another characteristic of the religious experience is «an extraordinary interest in the meaning of life, self-realization, and the implementation of the task set before us life» [10, p. 290].

Next feature is acute, even painful realization «... itself as a separate and unique creatures, and a desire to overcome the limitations of such a personality, becoming one with all things» [10, p.291].

Other features Erich Fromm called semantic. In connection with this aspect, he wrote: «Religion in their teachings, as well as in their rituals, speaks a language different from that which we use in everyday life, it is the language of symbols» [10, p. 303]. There Erich Fromm was able to identify the main elements of any particular religious system.

Considering the development of religion, he said that since the Middle Ages begin to appear shoots of a new religion - «industrial». The development of religion and philosophy since the Middle Ages is complex, says the analyst. It is characterized by a struggle between two principles: the Christian spiritual tradition in the theological and philosophical forms of idolatry and pagan traditions. This struggle has taken many different forms, with the result that there is, in the words of Erich Fromm, «religion of industrialism and cyber era». 
The first step towards such a religion was made by M. Luther, one of the founders of Protestantism. According to Erich Fromm, industrial religion is incompatible with true Christianity. It reduces people to the status of servants of the economy and created their own hands machines.

Erich Fromm divides all religions are authoritarian and humanistic. And issues, including those associated with the division of religion, he dedicates his work «Psychoanalysis and Religion».

Telling about the fundamental principles of the division of religion in authoritarian and humanistic, drew attention to the fact that in this case the principle of division into theistic nor theistic in this case does not work, there is more talking about human relationships, man's relation to religion and religion to the man «It is clear that the distinction between authoritarian and humanistic religion is not the same as the distinction between theistic and non-theistic religion, religion in the narrow sense and philosophical systems of religious character: it is not a system of thought as such, but in human terms, underlying these exercises». Then he adds: «Pondering this question, it should be remembered that his rational discussion impossible, as long as we are talking about» religion in general «and not single out any type of religion and religious experience. A description of all kinds of religion is hardly appropriate here, we will not discuss today, even many of the things that is interesting from a psychological point of view. So I will do just one distinction which, in my opinion, is the most significant. It applies to nontheistic, and theistic religions: it is - the distinction between authoritarian and humanistic religion».

When asked what an authoritarian religion, Erich Fromm citing «Oxford Dictionary», writes that in the dictionary when attempting to determine the religion in general, given more precise definition of authoritarian religion: «Religion is the recognition of a man of some higher unseen power that controls his destiny and requiring obedience, reverence and worship». In an authoritarian religion, according to Erich Fromm»... the emphasis is on the fact that a man standing outside runs higher power. But it makes the authoritarian and the idea that this force, dominating, is authorized to require 'obedience, reverence and worship». I distinguish the word «authorized» because it indicates that the reason for worship, obedience and reverence are not moral qualities of the deity, not love or justice, but the fact that it dominates, that is has power over man. Moreover, the word implies that a higher power has the right to force a person to worship it, and the rejection of the veneration and obedience means committing sin».
According to Erich Fromm: «An essential element of authoritarian religion and authoritarian religious experience is a complete capitulation to the power that is beyond human. The main virtue of this type of religion is the obedience, the worst $\sin$ - disobedience. As far as the all-powerful deity recognized and omniscient, so a person is considered powerless and insignificant, he sought the favor of the deities or assistance only in case of complete submission. Obedience strong power - one of the ways in which people avoid loneliness and limited. In the act of surrender, he loses the independence and integrity as an individual, but acquires a sense of security, becomes a part of the awe-inspiring power».

Erich Fromm believes that «Calvin's theology gives us a picture of the authoritarian, theistic thinking. «For I will not call it humility - says Calvin - if you expect to have if something else is ... We cannot afford to think about the way we should think, not entirely despise anything that might seem better our features. Humility is sincere obedience of the mind, full of deep sense of falling and poverty; because this is the usual description of his Word of God» [11, p. 681].

The experience, which describes Calvin - complete contempt for himself, obedience of the mind, the performance of its scarcity - the essence of all authoritarian religions, whether they are clothed in secular or theological language». Therefore, a feature of authoritarian religion Fromm is that «God is a symbol of power and strength. He is sovereign, as it has the supreme authority, and man, on the contrary, absolutely powerless» [12, p. 141].

According to Erich Fromm, secular authoritarian religion responds to the same principles. He emphasizes that in an authoritarian religion, God is a symbol of power and strength. He is Supreme Being, because it has the highest authority, and the person in comparison with him completely powerless. He writes: «The secular authoritarian religion follows the same principle. The life of the individual is considered to be insignificant, and human dignity just believes in denying its dignity and power. Most authoritarian religion posits an abstract and distant ideal, almost has no connection with the real lives of real people. For such ideals as «life after death» or «the future of humanity» can be sacrificed life and happiness of the people living here and now; believes the ends justify any means and become characters in the name of which religious or secular «elite» dispose of other people's lives» [7, p. 164-165].

In contrast to the authoritarian religion, according to Erich Fromm, humanistic religion pays more attention to the person, in fact so obviously this re- 
ligion called humanistic. The essence of the humanistic religion Erich Fromm defined as follows: «humanistic religion, on the contrary, elects the center of man and his forces. Man must develop your mind to understand themselves, their attitude toward others and their place in the universe. He must grasp the truth, in accordance with its limitations and its possibilities. He must develop the ability to love others, as well as to themselves, and to feel the unity of all living beings. He must have principles and norms that would lead him to the goal. Religious experience in this type of religion is the experience of oneness with all, based on the relationship of man with the world, to comprehend the thought and love».

The place of the person in the humanistic religion and his goal he sees in following: «The purpose of human humanist religion to achieve the greatest strength, not the greatest impotence; virtue for selfrealization, not obedience. Faith is the reliability of the conviction; it is based on the experience of thoughts and feelings, rather than to blindly accept other people's opinions. The prevailing mood is joy, not suffering, and wine as an authoritarian religion. If humanistic religion theistic God in them is a symbol of the forces of man himself realized in his life, not a symbol of violence and domination, not a symbol of authority over a man» [7, p. 167].

The humanistic religions to which he refers, Buddhism, early Christianity, and others are a symbol of their own powers of man that he strives to implement in their lives. This religion focused on the man and his abilities. Erich Fromm believes that we can take as an example a number of religions, but a special feature of humanistic religion more prominently identified in Buddhism: "As examples of humanistic religions can serve as early Buddhism, Taoism, the teachings of Isaiah, Jesus, Socrates, Spinoza, in some areas Jewish and Christian religions (especially mysticism), the religion of Reason during the French Revolution ... One from the best examples of early humanistic religion is Buddhism.

Buddha - a great teacher, he is the «awakened» who knows the truth about human existence. He tells on behalf of no supernatural power, but the mind and turns to every man, that he applied his own mind and sees the truth that the Buddha was able to see first. If a person makes at least one step closer to the truth, he must strive to live by developing the ability to reason and love for all human beings. Only to the extent that he succeeds, he can free himself from the shackles of the irrational passions. Although a person and must, according to Buddhism, to recognize its own limits, it should also become aware of their inner strength. The concept of nirvana as a fully awakened state of consciousness - it is not a concept of helplessness and obedience, but, on the contrary, the concept of the highest human power».

One of the stories of the Buddha is a good illustration of this situation: «... the rabbit fell asleep under the mango tree. Suddenly, he heard a terrible noise. Deciding that the world comes to an end, he began to run. When the other rabbits saw this, they asked him, «Why are you running so fast? «He replied: «There comes the end of the world». Hearing this, the rabbits began to run after him. The deer saw rabbits and asked them: "Why are you running so fast?» And they replied: «We run because the end of the world is near»». And the deer ran with them. And so one after the other animals began to run until all the animal kingdom is not turned into a stampede, which certainly would have ended badly. When the Buddha, who at the time lived as a wise man - one of the many forms of its existence, - I saw that the animals fled, he said, the last of them, why they fled. «Because it is the end of the world», - they said. «That's not true - said the Buddha - the world has not yet come to an end. To find out why they think so, he started asking all the animals came to the deer, and, finally, to the rabbits. When rabbits were told that they run, because the end of the world comes, he asked what kind of rabbit told them about it. They pointed to the one who ran the first. The Buddha asked the rabbit, "Where have you been and what he did when you thought, if this was the end of the world?» The rabbit said: «I was sleeping under a mango tree» - «You probably heard the noise of the falling of the fetus, - said the Buddha - the noise woke you, you got scared and thought that comes to an end. Let's go to the tree and see if this is true.» They went to the tree and found that this is what happened. So the Buddha saved the animal kingdom from destruction. We have given this history not only as one of the first examples of analytical research into the causes of fear and rumors; It also captures the spirit of Buddhism is good, love and care with respect to the creation of wildlife and at the same time a deep, rational understanding of the world and confidence in human power».

Zen - Buddhism, which is a later form of Buddhism, is more anti-authoritarian character of Zen Buddhism, later Buddhist sect, anti-authoritarians to an even greater extent. According to Zen, the knowledge is of no value if you do not grow out of us; no authority, no one teacher cannot teach us anything except the doubt; speech and thought systems is dangerous, because they are easily converted into objects of worship. Life itself should be perceived and experienced in its flow; this is the virtue» [7, p. 167]. 


\section{References}

1. Jung C.G. Psychology and Religion. L., 1970. 58p. Translation Rutkevich A.M. //www.koob.ru./ - P. 3.

2. Jung C.G. Modern Man in Search of a Sorel. - L, 1970. - 137 p.

3. Jung C.G. Affect civilization // C.G. Jung, M. Foucault Matrix madness. - M.: The Algorithm, EKSMO, 2006. - 384 p.

4. Popov M.A. Freudianism and religion. - M.: «Science», 1985. -199 p.

5. Jung C.G. The Collected Works. - L, 1959. - Vol. 11. - 464 p.

6. Popov M.A. Freudianism and religion. - M.: «Science», 1985. -199 p.

7. Fromm E. Psychoanalysis and Religion // Twilight of the Gods. Nietzsche, Freud, E. Fromm, Camus, Sartre, Jean-Paul. Trans. to English A. Yakovlev. - M., «Politizdat», 1990. - 150 p.

8. Fromm E. Zen Buddhism and psychoanalysis E. Fromm // The crisis of psychoanalysis. Zen Buddhism and Psychoanalysis / Translated from English .; PS Foreword Gurevich. - M.: Iris Press, 2004. - 304 p.

9. Fromm E. To have or to be. - M., 1990. - $141 \mathrm{~s}$.

10. Fromm E. Psychoanalysis and Religion // To have or to be. - M., 1990. - 237 s..

11. Calvin Iohannes Institutes of the Christian Religion. - Presbyterian Board of Christian Education, 1928. - P. 681.

12. Fromm E. Escape from Freedom. - Farrar \& Rinehart, 1941. - P. 141. 